\title{
The moderating effects of gender and education level on safe food handling intention among consumers in Sibu, Malaysia: based on the Theory of Planned Behavior
}

\author{
1, ${ }^{*}$ Genevie, E.R., ${ }^{1}$ Ungku Fatimah, U.Z.A., ${ }^{2}$ Samuel, L., ${ }^{3}$ Nuzul, N.J., ${ }^{3}$ New, C.Y. and \\ ${ }^{3,4}$ Son, R. \\ ${ }^{1}$ Department of Food Service and Management, Faculty of Food Science and Technology, Universiti Putra \\ Malaysia, 43400 Serdang, Selangor, Malaysia \\ ${ }^{2}$ Department of Molecular Biology, Faculty of Resource Science and Technology, Universiti Malaysia \\ Sarawak, 94300 Kota Samarahan, Sarawak, Malaysia \\ ${ }^{3}$ Department of Food Science, Faculty of Food Science and Technology, Universiti Putra Malaysia, \\ 43400 UPM Serdang, Selangor, Malaysia \\ ${ }^{4}$ Food Safety and Food Integrity, Institute of Tropical Agriculture and Food Security, Universiti Putra \\ Malaysia, 43400 UPM Serdang, Selangor, Malaysia
}

\begin{abstract}
Article history:
Received: 21 August 2019

Received in revised form: 18

September 2019

Accepted: 20 September

2019

Available Online: 10 October 2019
\end{abstract}

Keywords:

Multi-group analysis,

Moderator,

Consumer,

Permutation,

Safe food handling,

Theory of Planned Behavior

DOI:

https://doi.org/10.26656/fr.2017.4(2).299

\begin{abstract}
The consumers who did not comply with safe food-handling practices also contributed to the occurrence of food contamination. This study adapted the Theory of Planned Behavior (TPB) to examine the moderating effect of gender and level of education differences that influence the intention of safe food handling at home. A total of 623 consumers based in Sibu, Malaysia completed a questionnaire that measured attitude, subjective norm, perceived behavior control (PBC), and intention. Based on PLS-SEM multi-group analysis (PLS-MGA) by permutation approach, gender demonstrated no moderating effect on the TPB relationships in each state. Meanwhile, the level of education was a significant moderator between PBC and intention. In this relationship, it was indicated that PBC for consumers from lower education group was stronger than their counterparts. These results offered useful information for local authorities or educational institutions to gain a better understanding of consumer behavior towards safe food handling, allowing the authorities to develop intervention accordingly.
\end{abstract}

\section{Introduction}

Food is vital for human to grow. Food is considered to be safe if it is not harmful to health. Nevertheless, the risk of food contamination from processing to consumers' consumption has become a global issue nowadays. The possibility of food contamination during processing occurred due to existing contaminants in raw food combined with improper cleaning, transportation, heat treatment, packaging, and storage (Nerín et al., 2016).

In the southeast Asia region, more than 150 million people were infected with foodborne diseases (FBD) with more than 175,000 reported deaths every year (World Health Organization, 2015). Malaysia still has the highest number of food poisoning cases compared to other countries (Ministry of Health Malaysia, 2016, 2017). In Sarawak, a total of 805 cases of poisoning were reported in 2010 (Berita Nasional Malaysia, 2011) and this number increased to 1,017 in 2014 (Boon, 2014). Food contamination does not only occur in premises such as hotels or restaurants; households are also the main source of foodborne pathogens transmission. Such cases are due to food mishandling among consumers including poor personal hygiene, cross-contamination, and violation of time-temperature control (European Food Safety Authority and European Centre for Disease Prevention and Control, 2016; Kamala and Kumar, 2018).

Improving safe food handling behavior among consumers should minimize the number of FBD cases, as recommended by the European Association for Food Safety (Flynn et al., 2019). It was believed that an engagement in particular behavior can be explained by the individual's intention (Ajzen, 1991). The intention of safe food handling may influence consumer's behavior, causing them to be more likely to practice food safety measures. 
Theory of Planned Behavior (TPB) was developed by Ajzen (1991) after the revision of the Theory of Reasoned Action (TRA). Both theories described how behavior was affected by intention as a motivating factor. Note that the motivating factor was indicated by an individual's willingness and effort to perform the behavior. The existence of perceived behavior control (PBC) as one of TPB components differentiated these theories. Based on TPB, intention was explained through attitude, subjective norm, and PBC. Attitude is defined as consumer's evaluation of safe food handling while the subjective norm is the expectation of the people who have a close relationship with consumers in-charge of food handling. Apart from that, the PBC is denoted as the perceived easiness of safe food handling. Alternatively, PBC also includes consumers' selfefficacy, in other words, if they are personally able to handle food safely (Ajzen, 2002).

Most of the previous studies reported that females are more conscious about food safety compared to males. The findings indicated that females are good at food preparation, handling, and storage (Sanlier et al., 2012; Sanlier and Konaklioglu, 2012). Traditionally, females are frequently involved in food preparation at home, contributing to their prioritization of kitchen hygiene (Lazou et al., 2012; Hassan and Dimassi, 2014; Omari et al., 2018). Females are also more involved in the preparation of food at home because they enjoy doing the task and it becomes a part of their daily habit (Turnbull-Fortune and Badrie, 2014). Due to these reasons, females performed better than males in food preparation.

Nonetheless, it has been argued that males are better than females in some food safety practices. Females are known to be aware of food poisoning outbreaks, but males are reported to have more experience with food poisoning. Therefore, males are more concerned about the proper handling of food such as separating food using different containers and identifying the recommended temperature of refrigeration to slow down the growth of microorganisms (Al-Shabib et al., 2016; Zeeshan et al., 2017).

Previous studies also found that those with high education levels have good level of knowledge, attitude, and practice (KAP) in relation to food safety (Oladoyinbo et al., 2015; Faremi et al., 2018). Highlyeducated respondents such as university or college graduates have better KAP because they are more likely to have attended courses related to food safety (Pepple, 2017). Due to this reason, they have higher awareness about the major pathogens that can cause FBD (Hayajneh et al., 2016).
On the other hand, there were also studies proving that the level of education is not related to KAP in food safety (Alrabadi et al., 2013). Individuals with higher education do not necessarily have better KAP in food safety. Somewhat surprisingly, this group is reported as being more often infected by FBD compared to their counterparts (Osagbemi et al., 2010). Based on these observations, it is possible to establish a relationship between education level and safe food handling intention.

As a result of the above discussion shows that the presence of gender and education level would moderate the relationship between attitude, subjective norm and PBC with safe food handling intention. Thus, the research model and hypotheses for this study were developed as shown in Figure 1.

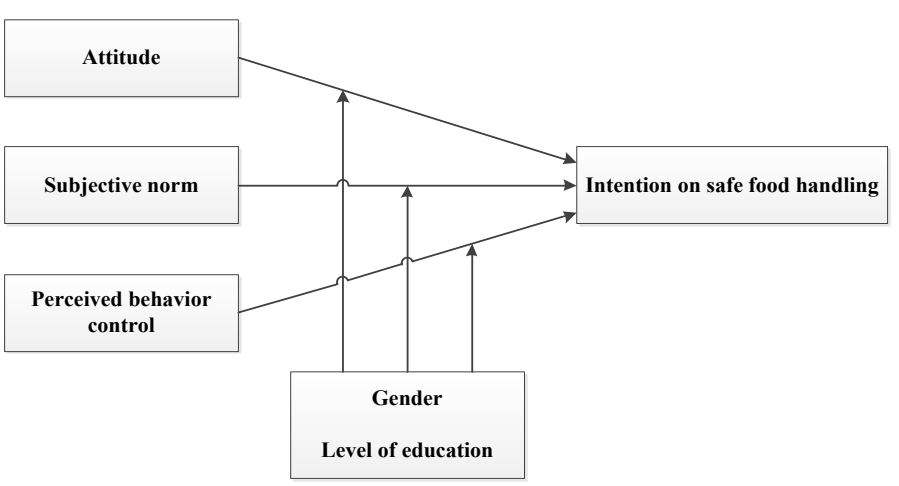

Figure 1. Research model

\section{Hypotheses:}

H1: The relation between attitude, subjective norm, and $\mathrm{PBC}$ with intention is moderated by gender.

$\mathrm{H} 2$ : The relation between attitude, subjective norm, and $\mathrm{PBC}$ with intention is moderated by education level.

This study is aimed to predict the intention of safe food handling that is moderated by gender and level of education among consumers in Sibu, Malaysia.

\section{Materials and method}

\subsection{Data collection}

A self-reporting questionnaire that was distributed by survey forms was used as the research instrument. A total of 800 questionnaires were distributed in six major shopping centers in Sibu, Malaysia. This survey targeted consumers that were over 20 years old and those who prepared food on a regular basis at home. Respondents were informed about the purpose of the survey and their consent was obtained in the participation of this study. Data collection was done over a period of five months. A total of 623 of 800 completed questionnaires were used for the final analysis, contributed to a response rate of $77.9 \%$. To confirm the minimum sample size for this 
study, G*Power 3.1.9.2 software was used to calculate the estimation based on the number of predictors, effect size, and statistical power, which was equivalent to 77 samples.

\subsection{Survey design}

The questionnaire was divided into two main sections; i) section A contained seven questions concerning the demographic profiles; and ii) section $\mathrm{B}$ contained the TPB constructs where there are four constructs with each having 5 questions adapted from existing literature, making a total of 20 questions (Table 1). For each question, respondents were required to rank their opinions on a 5-point Likert scale ranging from 1 (strongly agree) to 5 (strongly disagree).

\subsection{Statistical analysis}

The data collected were tested with the following sequence: common method bias (CMB), outer measurement model evaluation and moderation effects. Harman one-factor test and variance inflation factor (VIF) were employed to evaluate the data CMB. IBM SPSS Statistics 20 were used to perform the Harman one -factor test while VIF was determined using the SmartPLS 3.0 software (Ringle et al., 2015). In addition,

Table 1. Questionnaire for the TPB constructs
SmartPLS 3.0 software was used to perform the Partial least Squares Structural Equation Modelling (PLS-SEM) analysis to examine the hypotheses for non-normal data distribution and small sample size (Hair et al., 2017). The multi-group analysis (MGA) was used to determine the effect of gender and level of education as moderators on safe food handling intention.

\section{Results}

\subsection{Descriptive analysis}

Table 2 shows the demographic characteristics of the 623 respondents who participated in this study. Most of them were between 30 and 39 years old, employed, and prepared food at home for at least 3 days per week.

\subsection{Common method bias (CMB)}

Data for this study was gained through a similar selfreported questionnaire, warranting the use of Harman's one-factor test to examine the CMB (Podsakoff et al., 2003). It was indicated that the first factor explained $14.46 \%$ of the total variance. As the value was below $50 \%$, it can be concluded that the issue pertaining to CMB had not been detected (Tan et al., 2017). In addition, the presence of CMB was also detected based on the VIF that was higher than 3.3 (Kock, 2015).

Constructs Description of measurement items

A1: Washing food utensils using a sanitiser is a safe practice.

A2: Leaving cooked food at room temperature for more than 2 hours is harmful to health.

AT A3: Consuming expired food, without inspecting the changes in its smell and taste, will increase the risk of getting a foodborne illness.

A4: It is necessary to store raw food and cooked food separately.

A5: Reheating leftover food until it steams or boils is safe.

S1: My family thinks that I should cover my hair during food preparation.

S2: My family expects that I wash my hands with soap and water, after touching my face, nose, ears, and mouth.

SN S3: My family wants me to wash my hands with soap and water after using the toilet.

S4: My family expects me to wash my hands before touching meat/raw chicken. Nik Rosmawati et al. (2015)

S5: My family thinks I should handle food hygienically in the household.

P1: I like learning about how to keep my food safe for consumption.

P2: I am concerned about getting food poisoning.

Bai et al. (2014)

Majowicz et al. (2015)

Majowicz et al. (2015)

PBC P3: I am confident that I can cook safe, healthy meals for myself and my family. Majowicz et al. (2015)

P4: I perceive that I have total control over safe food handling in the household. Bai et al. (2014)

P5: It's totally up to me whether I handle food hygienically in the household.

T1: I plan to make an effort to prepare food hygienically with every meal.

Bai et al. (2014)

T2: I want to make an effort to prepare food hygienically with every meal.

INT T3: I am expected to prepare food hygienically at every meal.

T4: I aim to make an effort to prepare food hygienically with every meal.

T5: It is very likely that I will prepare food hygienically with every meal.
Mullan et al. (2013)

Mullan et al. (2013)

Mullan et al. (2013)

Mullan et al. (2013)

Shapiro et al. (2011)

Notes: $\mathrm{AT}=$ Attitude, $\mathrm{SN}=$ Subjective norm, $\mathrm{PBC}=$ Perceived behavior control, $\mathrm{INT}=$ Intention 
Table 2. Demographic profile of respondents

\begin{tabular}{llc}
\hline & Characteristics & Percentage (\%) \\
\hline \multirow{2}{*}{ Gender } & Male & 45.3 \\
& Female & 54.7 \\
\hline \multirow{3}{*}{ Age (years) } & $20-29$ & 21.2 \\
& $30-39$ & 34.3 \\
& $40-49$ & 26.6 \\
& 50 and above & 17.8 \\
\hline \multirow{3}{*}{ Education level } & Primary school and below & 31.6 \\
& Secondary school & 35.2 \\
\multirow{2}{*}{ Employment status } & Tertiary school and above & 33.2 \\
\hline \multirow{3}{*}{ Number of persons in the family } & Yes & 61.8 \\
& No & 38.2 \\
\hline \multirow{3}{*}{ Number of children in the family } & $1-2$ & 25 \\
& $3-5$ & 41.4 \\
& 6 and more & 33.5 \\
\hline \multirow{2}{*}{ Frequency of food preparation at home $3-6$ days per week } & 17.8 \\
& 0 & 32.4 \\
& Less than 3 days per week & 33.1 \\
& 2 & 16.7 \\
\hline
\end{tabular}

Nevertheless, the VIF for all latent variables ranged between 1.00 and 1.22. Thus, it was confirmed that the data set was free from any CMB issue.

\subsection{Outer measurement model assessment}

Table 3. Result of the measurement model

\begin{tabular}{ccccc}
\hline Construct & Indicator & Loading & CR & AVE \\
\hline \multirow{6}{*}{ AT } & A1 & 0.641 & 0.773 & 0.534 \\
& A2 & 0.811 & & \\
& A3 & 0.537 & & \\
& A4 & (deleted) & & \\
& A5 & -0.63 & & \\
& (deleted) & & \\
\hline \multirow{4}{*}{ SN } & S1 & 0.691 & 0.812 & 0.526 \\
& S2 & 0.836 & & \\
& S3 & 0.496 & & \\
& S4 & (deleted) & & \\
& S5 & 0.743 & & \\
\hline \multirow{5}{*}{ PBC } & P1 & 0.581 & & \\
& P2 & 0.622 & 0.798 & 0.502 \\
& P3 & 0.82 & & \\
& P4 & 0.697 & & \\
& P5 & 0.414 & & \\
& & (deleted) & & \\
\hline \multirow{5}{*}{ INT } & T1 & 0.923 & 0.951 & 0.796 \\
& T2 & 0.922 & & \\
& T3 & 0.865 & & \\
& T4 & 0.912 & & \\
\hline
\end{tabular}

The reliability and validity were examined for the assessment of the measurement model. Internal consistency reliability was measured through composite reliability (CR) while the outer loadings were used to measure indicator reliability. Furthermore, the average variance extracted (AVE) was used to evaluate convergent validity. As depicted in Table 3, all CR values exceeded 0.7 while AVE exceeded by more than 0.5 (Hair et al., 2017). Items with outer loadings that were less than 0.4 were deleted to increase the CR and AVE as factor loading should exceed the threshold of 0.6 (Chin et al., 1997).

The discriminant validity (DV) was assessed using heterotrait-monotrait (HTMT) ratio of correlations approach. Based on the most outperform and high sensitivity rate criterion (HTMT $<0.85$ ), it was confirmed that the DV was achieved (Henseler et al., 2015), as shown in Table 4.

Table 4. Discriminant validity result

\begin{tabular}{lcccc}
\hline & Attitude & Intention & Norms & PBC \\
\hline Attitude & & & & \\
Intention & 0.499 & & & \\
Norms & 0.629 & 0.609 & & \\
PBC & 0.349 & 0.335 & 0.228 & \\
\hline
\end{tabular}

\subsection{Moderating effect}

Since the moderator variable was not continuous, the moderating effect was determined based on group 
comparisons by multi-group analysis (MGA). The permutation approach was adopted as the analysis did not meet the prerequisite of distributional presumption (Hair et al., 2017). Afthanorhan et al. (2015) proposed that a permutation test was appropriate to determine the effects of categorical variables in the relationship between exogenous and endogenous constructs.

Moreover, dichotomisation was a common technique used when the moderating variables were divided into two value categories. The level of education had to be transformed into a categorical variable, while no further refinement was required for gender (Henseler and Fassot, 2010). The dichotomisation process was executed using the median split method in SPSS.

Based on Table 5, consumer's gender did not moderate their attitude, subjective norm, and PBC towards intention on safe food handling. Although gender was not a significant moderator, the comparison between the three components of TPB revealed that male (path coefficient $=0.419$ ) and female (path coefficient= 0.391) had a greater effect on the relationship between the norm and intention. Apart from that, the level of education had no significant effect as a moderator for the relationship between attitude and subjective norm with intention. Nevertheless, education only moderated the relationship between $\mathrm{PBC}$ and safe food handling intention with a significant difference of a $5 \%$ level between low education level (path coefficient $=0.320$ ) and high education level (path coefficient $=0.165$ ), as shown in Table 6 . The results stipulated that the path strength of low education level was stronger than the high education level.

\section{Discussion}

Most previous studies only examine the direct relationship between the TPB variables with intention in safe food handling. These gaps are evident in Mullan and Wong (2009); Mullan et al. (2013); and Bai et al. (2014) studies. Therefore, the purpose of this study was to examine the effect of gender and level of education as moderators towards safe food handling. Interestingly, gender did not moderate any relationship between determinants in TPB model with intention in safe food handling. This finding shows that gender is not a factor that influences the intention of safe food handling. Generally, safe food handling should be practiced by everyone regardless of their gender. Either male or female, both are involved in food handling at home and show equal concerns about food hygiene (Missagia et al., 2013).

It is the responsibility of the food handler to ensure that the food consumed by their family members are safe despite previous studies demonstrating that women's role is more dominant in this regard (Meysenburg et al.,

Table 5. Moderating effect of gender

\begin{tabular}{|c|c|c|c|c|c|c|c|c|}
\hline $\begin{array}{l}\text { Structural } \\
\text { path }\end{array}$ & $\begin{array}{l}\text { Path } \\
\text { Coefficients } \\
\text { Original } \\
\text { (Male) }\end{array}$ & $\begin{array}{l}\text { Path } \\
\text { Coefficients } \\
\text { Original } \\
\text { (Female) }\end{array}$ & $\begin{array}{l}\text { Path } \\
\text { Coefficients } \\
\text { Original } \\
\text { Difference } \\
\text { (Male - } \\
\text { Female) }\end{array}$ & $\begin{array}{l}\text { Path } \\
\text { Coefficients } \\
\text { Permutation } \\
\text { Mean } \\
\text { Difference } \\
\text { (Male - } \\
\text { Female) }\end{array}$ & $2.5 \%$ & $97.5 \%$ & $\begin{array}{l}\text { Permutation } \\
\text { p-Values }\end{array}$ & Remarks \\
\hline $\begin{array}{l}\text { Attitude } \\
-> \\
\text { Intention }\end{array}$ & 0.122 & 0.193 & -0.070 & 0.002 & -0.139 & 0.139 & 0.322 & $\begin{array}{l}\text { Not } \\
\text { supported }\end{array}$ \\
\hline $\begin{array}{l}\text { Norm -> } \\
\text { Intention }\end{array}$ & 0.419 & 0.391 & 0.028 & -0.001 & -0.127 & 0.127 & 0.655 & $\begin{array}{l}\text { Not } \\
\text { supported }\end{array}$ \\
\hline $\begin{array}{l}\text { PBC -> } \\
\text { Intention }\end{array}$ & 0.160 & 0.237 & -0.077 & 0.001 & -0.123 & 0.128 & 0.228 & $\begin{array}{l}\text { Not } \\
\text { supported }\end{array}$ \\
\hline $\begin{array}{l}\text { Structural } \\
\text { path }\end{array}$ & $\begin{array}{l}\text { Path } \\
\text { Coefficients } \\
\text { Original } \\
\text { (Low) }\end{array}$ & $\begin{array}{l}\text { Path } \\
\text { Coefficients } \\
\text { Original } \\
\text { (High) }\end{array}$ & $\begin{array}{l}\text { Path } \\
\text { Coefficients } \\
\text { Original } \\
\text { Difference } \\
\text { (Low - } \\
\text { High) }\end{array}$ & $\begin{array}{l}\text { Path } \\
\text { Coefficients } \\
\text { Permutation } \\
\text { Mean } \\
\text { Difference } \\
\text { (Low - } \\
\text { High) }\end{array}$ & $2.5 \%$ & $97.5 \%$ & $\begin{array}{l}\text { Permutation } \\
\text { p-Values }\end{array}$ & Remarks \\
\hline $\begin{array}{l}\text { Attitude } \\
-> \\
\text { Intention }\end{array}$ & 0.104 & 0.184 & -0.080 & 0.002 & -0.151 & 0.151 & 0.286 & $\begin{array}{l}\text { Not } \\
\text { supported }\end{array}$ \\
\hline $\begin{array}{l}\text { Norm -> } \\
\text { Intention }\end{array}$ & 0.315 & 0.442 & -0.127 & -0.001 & -0.139 & 0.135 & 0.070 & $\begin{array}{l}\text { Not } \\
\text { supported }\end{array}$ \\
\hline $\begin{array}{l}\text { PBC -> } \\
\text { Intention }\end{array}$ & 0.320 & 0.165 & 0.155 & 0.006 & -0.126 & 0.140 & 0.020 & Supported \\
\hline
\end{tabular}


2014; Zyoud et al., 2019). Simultaneously, family members also gave equal credence to both genders, although females are frequently considered better than males in food handling. Recently, males have also been proven to have good knowledge and practices regarding food safety as a result of positive influence by their parents at home (Mirzaei et al., 2018). Family support might boost the confidence of consumers to be more aware of handling the food safely. Based on this finding, gender failed as a moderator variable and did not strengthen the relationships among TPB components.

On the moderating effect of education level, the permutation approach indicated that education level moderates the interrelation between PBC and safe food handling intention. Consumers with higher education are expected to have more exposure to safe food handling, especially if they have a background in health sciences (Nazer Ali et al., 2018). Surprisingly, consumers of low education groups reinforce the relationship between the $\mathrm{PBC}$ and the intention of safe food handling. It implies that consumers with low education levels feel more accessible and comfortable to handle food safely than their counterparts. In other words, highly educated consumers may have more knowledge of safe food handling, but lower educated consumers are more concerned with food safety. This finding contradicts Veeck et al. (2015).

All in all, the highly educated group has an awareness of the importance of food safety, but certain factors inhibit its implementation. The lack of time is potentially the major contributing factor to the difference of intention between these two groups. Career demands may cause highly educated consumers to be less compliant or forget about safe food handling. Lack of time has been proven to be a deterrent factor for the implementation of safe food handling (Arendt et al., 2015; Wandolo et al., 2018), a logical explanation as $61.8 \%$ of consumers in this study are employed.

With their careers, those with higher education also have a more stable economic resource which allows them to hire housemaids to help with daily chores including food preparation (Alsayeqh, 2015). Lack of involvement may be the factor that makes them less applied safe food handling practices compared to those with lower education who prepare their own food. This point makes sense because only $29.5 \%$ of consumers in the study reported that they prepare food every day.

Despite that, the cross-sectional design did not allow cause and effect to be determined, but moderator and predictive effects can be observed (Sedgwick, 2014). The data for this study was based on self-reported surveys which may give rise to the bias issue. Moreover, only two categories of the sociodemographic profile were tested as the moderator.

\section{Conclusion}

By assessing the moderating effects, this study contributed to the current knowledge and delineated several useful implications for the accomplishment of food safety among consumers and the enhancement of food handling. Although only education level moderates the relationship between the PBC and intention, this outcome can be used in designing and implementing some useful strategies to educate consumers so that they will be more aware of food safety. Prospective and longitudinal studies are recommended to further understand the moderators' effect on TPB relationships. Future studies should be conducted such as in-depth interviews or observation approach to study the consumer's actual behavior in food handling at home. Apart from that, two or more moderators based on diverse sociodemographic factors are encouraged to be examined for TPB to predict consumer's behavior on food safety.

\section{Conflicts of Interest}

The authors declare no conflict of interest.

\section{Acknowledgment}

High appreciation was given to respondents who have voluntarily participated in this study. Not forgetting, thank you to Dr. Thavamaran Kanesan and his team for their proofreading service.

\section{References}

Afthanorhan, A., Nazim, A. and Ahmad, S. (2015). Permutation Test, Non-Parametric, and Confidence Set Approaches to Multigroup Analysis for Comparing 2 Groups Using Partial Least Square Structural Equation Modeling (PLS-SEM). International Journal of Mathematics and Statistics Studies, 3(4), 18-34. https://doi.org/10.9734/ AIR/2015/15218

Ajzen, I. (1991). The theory of planned behavior. Organizational Behavior and Human Decision Processes, 50, 179-211. https:// doi.org/10.1016/0749-5978(91)90020-T

Ajzen, I. (2002). Perceived Behavioral Control, SelfEfficacy, Locus of Control, and the Theory of Planned Behavior. Journal of Applied Social Psychology, 32(4), 665-683. https://doi.org/10.1111/ j.1559-1816.2002.tb00236.x

Al-Shabib, N.A., Husain, F.M. and Khan, J.M. (2016). 
Study on food safety concerns, knowledge and practices among university students in Saudi Arabia. Food Control, 73(Part B), 202-208. https:// doi.org/10.1016/j.foodcont.2016.08.005

Alrabadi, N.I., Al-Massad, M. and Alboqai, O. (2013). Food Safety: A Study of Jordanian Consumer's Knowledge and Practices. World Applied Sciences Journal, 22(1), 35-40. https://doi.org/10.5829/ idosi.wasj.2013.22.01.2949

Alsayeqh, A.F. (2015). Foodborne disease risk factors among women in Riyadh, Saudi Arabia. Food Control, 50, 85-91. https://doi.org/10.1016/ j.foodcont.2014.08.036

Arendt, S., Strohbehn, C. and Jun, J. (2015). Motivators and barriers to safe food practices: Observation and interview. Food Protection Trends, 35(5), 365-376. Retrieved from www.foodprotection.org/files/foodprotection-trends/Sep-Oct-15-arendt.pdf\%0D

Bai, L., Tang, J., Yang, Y. and Gong, S. (2014). Hygienic food handling intention. An application of the Theory of Planned Behavior in the Chinese cultural context. Food Control, 42, 172-180. https:// doi.org/10.1016/j.foodcont.2014.02.008

Berita Nasional Malaysia. (2011). Sarawak's "Hands Of Health Across The Nation" Campaign Kicks-off On Thursday. Retrieved October 20, 2018, from Berita Nasional Malaysia website: https:// www.nreb.gov.my/modules/web/pages.php? $\bmod =$ newsandsub $=$ news_viewandnid $=38$

Boon, P. (2014). State records 1,017 food poisoning cases till October. Retrieved from The Borneo Post website: https:// www.theborneopost.com/2014/12/12/state-records1017-food-poisoning-cases-till-october/\%0D

Chin, W.W., Gopal, A. and Salisbury, W.D. (1997). Advancing the Theory of Adaptive Structuration: The Development of a Scale to Measure Faithfulness of Appropriation. Information Systems Research, 8 (4), 342-367. https://doi.org/10.1287/isre.8.4.342

da Cunha, D.T., Stedefeldt, E. and de Rosso, V.V. (2014). The role of theoretical food safety training on Brazilian food handlers' knowledge, attitude and practice. Food Control, 43, 167-174. https:// doi.org/10.1016/j.foodcont.2014.03.012

European Food Safety Authority and European Centre for Disease Prevention and Control. (2016). The European Union summary report on trends and sources of zoonoses, zoonotic agents and food-borne outbreaks in 2015. EFSA Journal, 14(12), e04634. https://doi.org/10.2903/j.efsa.2016.4634

Faremi, F.A., Olatubi, M.I. and Nnabuife, G.C. (2018). Food Safety and Hygiene Practices among Food
Vendors in a Tertiary Educational Institution in South Western Nigeria. European Journal of Nutrition and Food Safety, 8(2), 59-70. https:// doi.org/10.9734/EJNFS/2018/39368

Flynn, K., Villarreal, B. P., Barranco, A., Belc, N., Björnsdóttir, B., Fusco, V., Rainieri, S., Saradottir, S.E., Smeu, I., Texeira, P. and Jörundsdóttir, H.Ó. (2019). An introduction to current food safety needs. Trends in Food Science and Technology, 84, 1-3. https://doi.org/10.1016/j.tifs.2018.09.012

Hair, J.F., Hult, G.T.M., Ringle, C.M. and Sarstedt, M. (2017). A Primer on Partial Least Squares Structural Equation Modeling (PLS-SEM). $2^{\text {nd }}$ ed. United States of America: SAGE Publications, Inc.

Hassan, H.F. and Dimassi, H. (2014). Food safety and handling knowledge and practices of Lebanese university students. Food Control, 40, 127-133. https://doi.org/10.1016/j.foodcont.2013.11.040

Hayajneh, F.M. Alnimer, M.A. Titi, H.H. and AbuZanat, M. (2016). Public Awareness about Two Foodborne Pathogens and Food Poisoning among Consumers in Jordan. American-Eurasian Journal of Agricultural and Environmental Science, 16(12), 1769-1775. https://doi.org/10.5829/ idosi.aejaes.2016.1769.1775

Henseler, J. and Fassot, G. (2010). Testing Moderating Effects in PLS Path Models: An Illustration of Available Procedures. In Vinzi, V.E., Chin, W.W., Henseler, J. and Wang, H. (Eds.). Handbook of Partial Least Squares: Concepts, Methods and Applications., p. 713-735. London, New York: Springer Heidelberg Dordrecht. https:// doi.org/10.1007/978-3-642-16345-6

Henseler, J., Ringle, C.M. and Sarstedt, M. (2015). A new criterion for assessing discriminant validity in variance-based structural equation modeling. Journal of the Academy of Marketing Science, 43(1), 115135. https://doi.org/10.1007/s11747-014-0403-8

Kamala, K. and Kumar, V.P. (2018). Food Products and Food Contamination. In Holban, A.M. and Mihai, G.A. (Eds.). Microbial Contamination and Food Degradation: Handbook of Food Bioengineering, p. 1-19. London, United Kingdom: Elsevier Inc. https:// doi.org/10.1016/B978-0-12-811515-2.00001-9

Kock, N. (2015). Common method bias in PLS-SEM: A full collinearity assessment approach. International Journal of E-Collaboration, 11(4), 1-10. https:// doi.org/10.4018/ijec.2015100101

Lazou, T., Georgiadis, M., Pentieva, K., McKevitt, A. and Iossifidou, E. (2012). Food safety knowledge and food-handling practices of Greek university students: A questionnaire-based survey. Food 
Control, 28(2), 400-411. https://doi.org/10.1016/ j.foodcont.2012.05.027

Lum, A.K., Albrecht, J.A., Yaseen, M., Litchfield, R. and Ritter-Gooder, P. (2013). Food-handling practices and knowledge among families with young children. Food Protection Trends, 33(6), 358-375.

Majowicz, S.E., Diplock, K J., Leatherdale, S.T., Bredin, C.T., Rebellato, S., Hammond, D., Jones-Bitton, A. and Dubin, J.A. (2015). Food safety knowledge, attitudes and self-reported practices among Ontario high school students. Canadian Journal of Public Health, 106(8), e520-e526. https://doi.org/10.17269/ CJPH.106.5213

Meysenburg, R., Albrecht, J.A., Litchfield, R. and RitterGooder, P.K. (2014). Food safety knowledge, practices and beliefs of primary food preparers in families with young children. A mixed methods study. Appetite, 73, 121-131. https:// doi.org/10.1016/j.appet.2013.10.015

Mirzaei, A., Nourmoradi, H., Abedzadeh Zavareh, M.S., Jalilian, M., Mansourian, M., Mazloomi, S., Mokhtari, N. and Mokhtari, F. (2018). Food Safety Knowledge and Practices of Male Adolescents in West of Iran. Open Access Macedonian Journal of Medical Sciences, 6, 908-912. https:// doi.org/10.3889/oamjms.2018.175

Missagia, S.V., Oliveira, S.R. and Rezende, D.C. (2013). Beauty and the beast: gender differences in foodrelated behavior. Revista Brasileira de Marketing, 12 (1), 149-165. https://doi.org/10.5585/ remark.v12i1.2441

Mullan, B.A., Wong, C. and Kothe, E.J. (2013). Predicting adolescents' safe food handling using an extended theory of planned behavior. Food Control, 31(2), $\quad 454-460 . \quad$ https://doi.org/10.1016/ j.foodcont.2012.10.027

Mullan, B.A. and Wong, C.L. (2009). Hygienic food handling behaviors. An application of the Theory of Planned Behavior. Appetite, 52(3), 757-761. https:// doi.org/10.1016/j.appet.2009.01.007

Nazer Ali, A., Lene, A., Prajapati, S.K. and Ahmed, N.Z. (2018). Self-reported association and determinants of KAP on food safety and hygiene among Private University Students in Kedah state, Malaysia. MOJ Bioequivalence and Bioavailability, 5(5), 256-262. https://doi.org/10.15406/mojbb.2018.05.00111

Nerín, C., Aznar, M. and Carrizo, D. (2016). Food contamination during food process. Trends in Food Science and Technology, 48, 63-68. https:// doi.org/10.1016/j.tifs.2015.12.004

Nik Rosmawati, N.H., Wan Manan, W.M., Noor Izani, N.J. and Nik Nurain, N.H. (2015). Validity and
Reliability of Food Safety Knowledge and Practices Questionnaire among Food Handlers. Health and the Environmental Journal, 6(1), 11-30.

Oladoyinbo, C.A., Akinbule, O.O. and Awosika, I.A. (2015). Knowledge of food borne infection and food safety practices among local food handlers in IjebuOde Local Government Area of Ogun State. Journal of Public Health and Epidemiology, 7(9), 268-273. https://doi.org/10.5897/JPHE2015.0758

Omari, R., Frempong, G.K. and Arthur, W. (2018). Public perceptions and worry about food safety hazards and risks in Ghana. Food Control, 93, 7682. https://doi.org/10.1016/j.foodcont.2018.05.026

Osagbemi, G.K., Abdullahi, A. and Aderibigbe, S.A. (2010). Knowledge, Attitude and Practice Concerning Food Poisoning among Residents of Okene Metropolis, Nigeria. Research Journal of Social Sciences, 1(5), 61-64.

Pepple, N. (2017). Environment and Food Poisoning: Food Safety Knowledge and Practice among Food Vendors in Garki, Abuja - Nigeria. Journal of Health Education Research and Development, 5(2), 1-4. https://doi.org/10.4172/2380-5439.1000217

Podsakoff, P.M., MacKenzie, S.B., Lee, J.Y. and Podsakoff, N.P. (2003). Common Method Biases in Behavioral Research: A Critical Review of the Literature and Recommended Remedies. Journal of Applied Psychology, 88(5), 879-903. https:// doi.org/10.1037/0021-9010.88.5.879

Ringle, C.M., Wende, S. and Becker, J.M. (2015). SmartPLS 3. Retrieved December 9, 2018 from SmartPLS website: from https://www.smartpls.com/ downloads

Sanlier, N., Bilici, S., Çelik, B. and Memi, E. (2012). Food Safety Knowledge and Practices of Nursing Students. Italian Journal of Food Science, 24, 242012.

Sanlier, N. and Konaklioglu, E. (2012). Food safety knowledge, attitude and food handling practices of students. British Food Journal, 114(4), 469-480. https://doi.org/10.1108/00070701211219504

Sedgwick, P. (2014). Cross sectional studies: Advantages and disadvantages. BMJ (Online), 348, 1 -2. https://doi.org/10.1136/bmj.g2276

Shapiro, M.A., Porticella, N., Jiang, L.C. and Gravani, R.B. (2011). Predicting intentions to adopt safe home food handling practices. Applying the theory of planned behavior. Appetite, 56(1), 96-103. https:// doi.org/10.1016/j.appet.2010.11.148

Tan, G.W.-H., Lee, V.H., Lin, B. and Ooi, K.-B. (2017). Mobile applications in tourism: the future of the tourism industry? Industrial Management and Data 
Systems, 117(3), 560-581. https://doi.org/10.1108/

IMDS-12-2015-0490

Turnbull-Fortune, S. and Badrie, N. (2014). Practice, behavior, knowledge and awareness of food safety among secondary and tertiary level students in Trinidad, West Indies. Food and Nutrition Sciences, 5, 1463-1481. https://doi.org/10.4236/ fns.2014.515160

Veeck, G., Veeck, A. and Zhao, S. (2015). Perceptions of Food Safety by Urban Consumers in Nanjing, China. The Professional Geographer, 67(3), 490501. https:// doi.org/10.1080/00330124.2015.1028514

Wandolo, M A., Ndiritu, D., Khayiya, R. and Mugendi, B.W. (2018). Barriers to the Implementation of Food Safety and Hygiene Principles (HACCP) in TVET and University Hospitality Schools in Kenya. International Journal of Scientific Research and Management, 6(7), 544-556. https:// doi.org/10.18535/ijsrm/v6i7.em05

World Health Organization. (2015). WHO Estimates of the Global Burden of Foodborne Diseases. Retrieved from World Health Organization website: https:// www.who.int/foodsafety/publications/ foodborne_disease/fergreport/en/\%0D

Zeeshan, M., Shah, H., Durrani, Y., Ayub, M., Jan, Z. and Shah, M. (2017). A Questionnaire-Based Survey on Food Safety Knowledge during Food-Handling and Food Preparation Practices among University Students. Journal of Clinical Nutrition and Dietetics, 3(2), 1-8. https://doi.org/10.4172/2472-1921.100052

Zyoud, S., Shalabi, J., Imran, K., Ayaseh, L., Radwany, N., Salameh, R., Sa'dalden, Z., Sharif, L., Sweileh, W., Awang, R. and Al-Jabi, S. (2019). Knowledge, attitude and practices among parents regarding food poisoning: A cross-sectional study from Palestine. BMC Public Health, 19, 1-10. https:// doi.org/10.1186/s12889-019-6955-2 